Article

\title{
The Household Cooking Sector in Nigeria: Environmental and Economic Sustainability Assessment
}

\section{Haruna Gujba ${ }^{1, \dagger}$, Yacob Mulugetta ${ }^{2, \dagger}$ and Adisa Azapagic ${ }^{1, \dagger}, *$}

1 School of Chemical Engineering and Analytical Science, The Mill, Sackville Street, The University of Manchester, Manchester M13 9PL, UK; E-Mail: haruna.gujba@gmail.com

2 Department of Science, Technology, Engineering, and Public Policy, University College London, Gower Street, London WC1E 6BT, UK; E-Mail: yacob.mulugetta@ucl.ac.uk

$\dagger$ All authors contributed equally to this work.

* Author to whom correspondence should be addressed; E-Mail: adisa.azapagic@manchester.ac.uk; Tel.: +44-(0)-161-306-4363.

Academic Editor: Witold-Roger Poganietz

Received: 4 April 2015 / Accepted: 12 June 2015 / Published: 18 June 2015

\begin{abstract}
This paper studies life cycle environmental impacts and costs of the household cooking sector in Nigeria from 2003 to 2030. Five scenarios are considered: business as usual, dominated by fuel wood stoves; low penetration of improved fuel wood and solar stoves, as planned by the government; high penetration of these stoves; increased use of fossil fuel stoves; and increased use of electric stoves. If business as usual (BAU) continues, the environmental impacts would increase by up to four times and costs by up to five times, mainly because of high fuel wood consumption. Implementing the government's plan to introduce improved fuel wood and solar stoves would yield no environmental advantages, as the proposed number of stoves is too low. A higher number of the advanced stoves would lead to significant improvements in some impacts but would worsen others so that some trade-offs are needed. From the economic perspective, the scenario with a high use of advanced stoves has the lowest total costs but its capital costs are three times higher than for BAU. The government should prioritise the introduction of advanced stoves to reduce health impact from indoor pollution and reduce pressures on biomass resources; however, this may require subsidies. Fossil fuel and electric stoves would also help to preserve biomass and reduce health impacts from indoor pollution but would lead to an increase in greenhouse gas emissions and depletion of fossil resources.
\end{abstract}


Keywords: economic assessment; household cooking; life cycle assessment; Nigeria; scenario analysis

\section{Introduction}

The household cooking sector is the largest consumer of energy in Nigeria, using around $80 \%$ of the total, $90 \%$ of which is derived from biomass, particularly fuel wood [1]. Although biomass is a renewable resource, the way and the rate at which it is consumed is unsustainable and needs interventions to increase the efficiency of use or find substitutes to ease the burden on the biomass stocks.

Although other sources of cooking energy are used in Nigeria, including liquefied petroleum gas (LPG), kerosene, and electricity, they are expensive compared to biomass, which is available at little or no cost. With over $60 \%$ of people earning less than $\$ 1$ per day [2], biomass stands as the preferred source of household cooking energy in Nigeria. The availability of electricity and other energy sources is also a major challenge, especially in rural areas. For example, only about $40 \%$ of the population is connected to the national grid $[3,4]$ with $90 \%$ of rural areas having unreliable or no electricity at all [5]. This virtually eliminates electricity as a source of cooking energy for almost half the population [6]. Urban dwellings, on the other hand, use electricity, as well as kerosene and LPG for cooking, although fuel wood still dominates owing to the high cost of other energy sources [1].

The reliance on fuel wood for the domestic energy supply has exacerbated deforestation, which is also contributing to desertification in some parts of the country [7,8]. The annual deforestation rate is estimated at around 3\% per year, which is equivalent to the loss of 410,000 hectares of forested land annually [8]. Another major concern is indoor air pollution from burning biomass in open fires and usually without chimneys, leading to respiratory diseases and premature deaths [9]. WHO [10] estimates 79,000 deaths per year in Nigeria from indoor air pollution, mainly caused by biomass burning. Deaths from acute lower respiratory infection in children younger than five years account for about $90 \%$ of the total number of deaths from indoor air pollution, with chronic obstructive pulmonary disease in adults of 30 years or over accounting for the rest. Furthermore, constant search for fuel wood represents a large burden for women, particularly in rural areas.

In an attempt to address the health issues and reduce the pressure on biomass resources, the government has in recent times developed plans for improving the efficiency of current cooking methods, dominated by traditional "three-stone" fuel wood stoves, as well as for introducing new technologies [11]. As a result, advanced cook stoves are starting to be deployed in Nigeria, albeit currently on a small-scale. For example, the German organisation Atmosfair has, thus far, distributed over 10,000 advanced stoves and the American C-Quest Capital has deployed around 6500 units, with the plans to increase distribution to 1.2 million over the next decade [12]. However, it is not clear what the environmental and economic implications of these technologies would be and how they would affect the sustainability of the sector in the future.

In an attempt to provide an insight into this subject, this study uses life cycle assessment (LCA) and economic analysis to evaluate the environmental and cost implications of the current and possible future 
household cooking sector in Nigeria. As far as we are aware, this is the first study of its kind for the household cooking sector in Nigeria.

\section{Methodology}

As shown in Figure 1, the methodology applied in this research consists of the following three steps:

1. definition of the current household cooking system and development of future scenarios, followed by data collection;

2. system modelling using life cycle assessment and economic analysis; and

3. estimation of life cycle environmental impacts and economic costs for the current cooking system and future scenarios.

The methodology is described in more detail in the following sections.

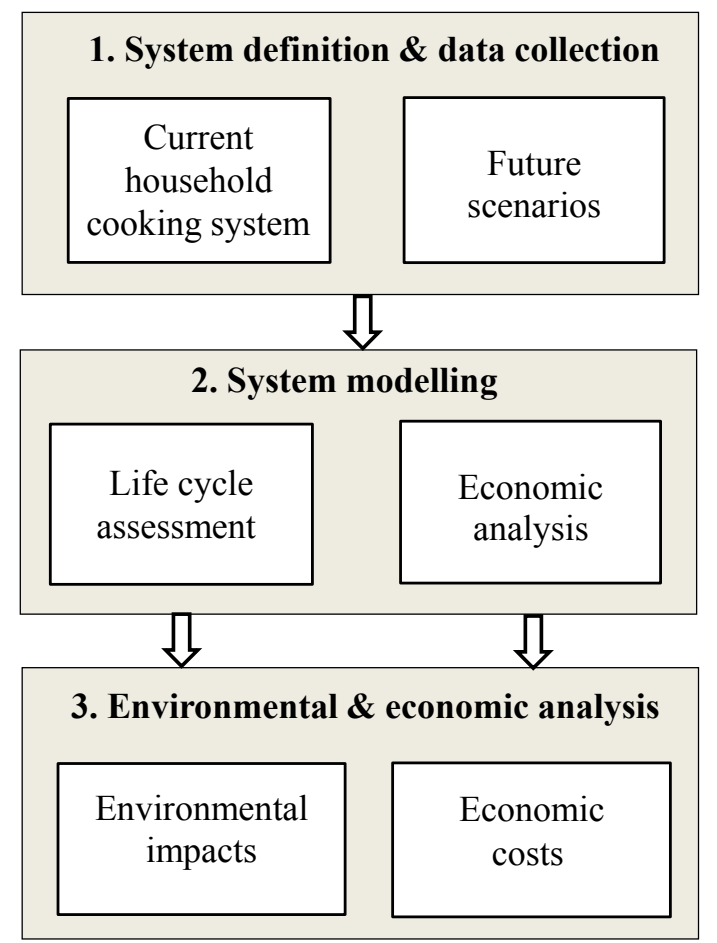

Figure 1. The methodology for environmental and economic analysis of the household cooking sector in Nigeria.

\subsection{System Definition and Data Collection}

As indicated in Figure 2, the system boundary is from "cradle to grave", including extraction and conversion of primary resources, cultivation of biomass, electricity and heat generation, construction and use of stoves, end-of-life waste management and transport. The following sections provide more detail on the current household cooking system, followed by the assumptions made for the scenarios. Data sources are also discussed below. 


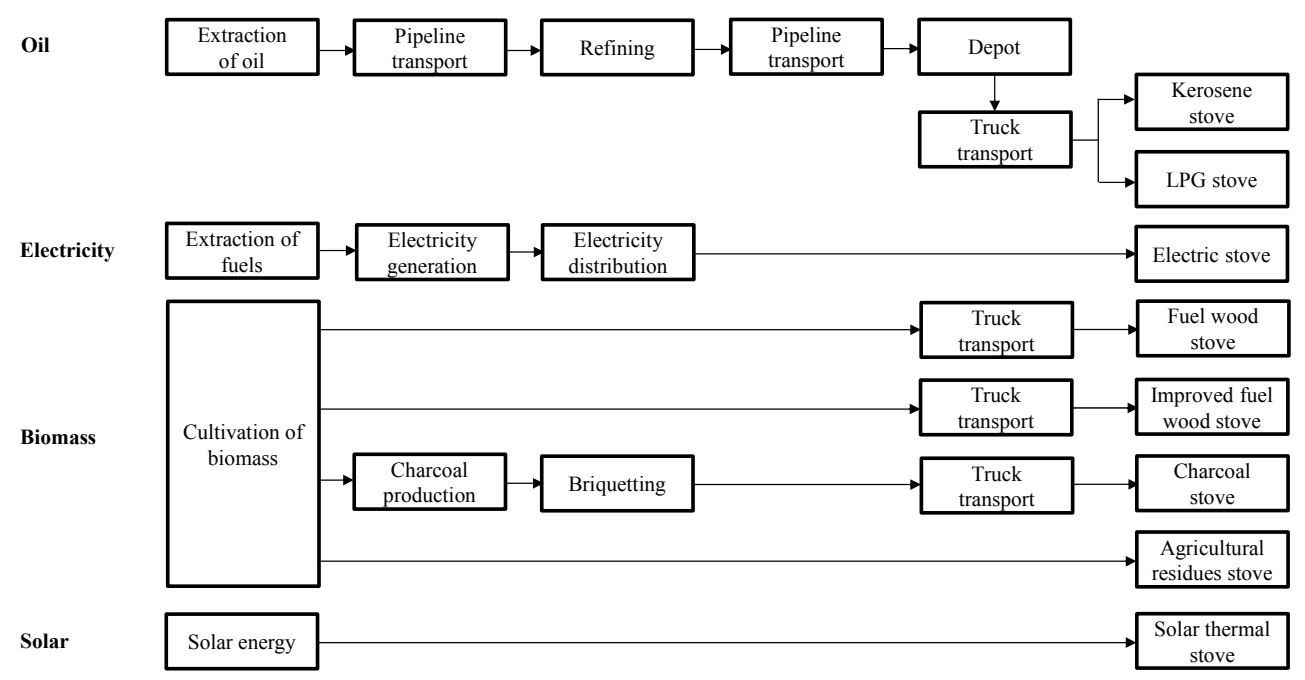

Figure 2. The household cooking sector and system boundaries. Extraction of primary resources is included in the analysis but not shown for simplicity. LPG: liquefied petroleum gas.

\subsubsection{Current Household Cooking System}

The characteristics of the current household system in Nigeria are summarised in Table 1. Owing to a limited availability, the data refer to the year 2003, for which the most complete data have been available [11]. These data are still considered representative of the current Nigerian household cooking system, as the overall features of the sector have not changed much. Thus, for consistency and as a reference point for future scenarios, 2003 is considered as the base year.

As can be seen from Table 1, the vast majority of stoves in Nigeria, particularly in rural areas, use fuel wood, which is burned in open-fire "three-stone" stoves. Other fuels used include charcoal, agricultural residues, kerosene and LPG; electric stoves are used mainly in urban areas. The data for the consumption of fuel wood, charcoal, kerosene and LPG have been obtained from United Nations Statistics Division (UNSD) [13] while those for agricultural residues and electricity have been estimated from Dayo et al. [14]. In total, 114 million tonnes of fuels were used for cooking in the base year. The lower heating values have been used to estimate the energy embodied in the fuels, which amounted to 1281.4 PJ annually. The total useful energy $U E$ obtained from different types of fuel has been calculated at $247.9 \mathrm{PJ} / \mathrm{year}$ by summing up the useful energy from the individual fuels $U E_{i}$, as follows:

$$
U E=\sum U E_{i}=\sum F E_{i} x \eta_{i}
$$

where $F E_{i}$ is the total energy consumption for fuel $i$ and $\eta_{i}$ is the efficiency of heat generation from that fuel; $\eta_{i}$ has been sourced from the Global Emission Model for Integrated Systems (GEMIS) database [15], together with the average yearly operating hours and unit capacities of the stoves. These data have been used to estimate the number of cooking stoves $N_{i}$ for each fuel type $i$ :

$$
N_{i}=U E_{i} /\left(C_{i} x T_{i}\right)
$$

where $C_{i}$ is the stove capacity for fuel $i$ and $T_{i}$ are the yearly operating hours of the stove for fuel $i$. The same approach has been used to calculate the useful energy and number of stoves for the scenarios. 
Table 1. Characteristics of the current household cooking sector (data for the base year 2003) $[1,13,15]$.

\begin{tabular}{|c|c|c|c|c|c|c|c|c|}
\hline Stove Type & $\begin{array}{c}\text { Number of } \\
\text { Stoves (1000s) }{ }^{\text {a }}\end{array}$ & $\begin{array}{c}\text { Unit Capacity } \\
(\mathbf{k W})\end{array}$ & $\begin{array}{c}\text { Efficiency } \\
(\%)\end{array}$ & $\begin{array}{c}\text { Stove Lifetime } \\
\text { (years) }\end{array}$ & $\begin{array}{c}\text { Operating Time } \\
\text { (hr/year) }\end{array}$ & $\begin{array}{c}\text { Amount of Fuel Consumed } \\
\text { (kt/year) }\end{array}$ & $\begin{array}{c}\text { Energy in Fuel Consumed } \\
(\mathrm{PJ} / \text { year })^{\mathrm{b}} \\
\end{array}$ & $\begin{array}{c}\text { Useful Energy } \\
\text { (PJ/year) }^{c}\end{array}$ \\
\hline Fuel wood & 19,565 & 2 & 18 & 5 & 1500 & 109,478 & 1173.6 & 211.3 \\
\hline Charcoal & 648 & 2 & 22 & 5 & 1500 & 936 & 31.9 & 7.0 \\
\hline Agricultural residue & 250 & 2 & 10 & 5 & 1500 & 2,807 & 27.4 & 2.7 \\
\hline Kerosene & 2407 & 2 & 55 & 10 & 1500 & 1,116 & 47.3 & 26.0 \\
\hline LPG & 56 & 2.5 & 60 & 10 & 1200 & 21 & 1.0 & 0.6 \\
\hline Electricity & 23 & 2.5 & 95 & 10 & 1200 & - & 0.26 & 0.25 \\
\hline Total & 22,949 & & & & & 114,358 & 1281.4 & 247.9 \\
\hline
\end{tabular}

Notes: ${ }^{\text {a: }}$ Estimated using Equation (2); ${ }^{\mathrm{b}}$ : Estimated based on the lower heating values as follows: fuel wood $=10.72 \mathrm{MJ} / \mathrm{kg}$, charcoal $=34.08 \mathrm{MJ} / \mathrm{kg}$, agricultural residue $=9.76 \mathrm{MJ} / \mathrm{kg}$, kerosene $=42.38 \mathrm{MJ} / \mathrm{kg}, \mathrm{LPG}=46.37 \mathrm{MJ} / \mathrm{kg}[15]{ }^{\mathrm{c}}$ : Estimated using Equation (1). 
The costs of the fuels and cooking stoves have been obtained from the sources listed in Table 2 and Table 3, respectively. It should be noted that the costs of fuel wood and agricultural residue differ greatly by area; while they are supplied at little or no cost in rural areas, they are sold at far higher prices in urban regions. Thus, the costs in Table 2 represent the market costs in urban areas.

Table 2. Costs of fuels in Nigeria in the base year (2003).

\begin{tabular}{cccc}
\hline Fuel Type & Cost & Reference & Cost (US\$2014/tonne) $^{\text {a }}$ \\
\hline Fuel wood & N3.00 per kg & {$[16]$} & 29 \\
Charcoal & N5.00 per kg & {$[16]$} & 50 \\
Agricultural residue & N0.50 per kg & {$[16]$} & 5 \\
Kerosene (imported) & N43.50 per litre & {$[17]$} & 545 \\
Kerosene (domestic) & N31.50 per litre & {$[18]$} & 394 \\
LPG (domestic) & N80.00 per kg & {$[19]$} & 789 \\
\hline
\end{tabular}

Notes: a: The cost in Nigerian Naira (N) in 2003 have first been converted to US\$2003 using the exchange rate of US\$1 $=$ N130, then to US\$214 using the Consumer Price Index [20].

Table 3. Capital costs of stoves in the base year (2003).

\begin{tabular}{ccc}
\hline Stove Type & Capital Cost (US\$2014/kW) & Reference \\
\hline Biomass & $0.6^{\mathrm{a}}$ & {$[16]$} \\
LPG & 76.2 & {$[19]$} \\
Kerosene & 6.1 & {$[16]$} \\
Electric & 76.2 & {$[19]$} \\
\hline
\end{tabular}

Notes: a: The actual capital cost of biomass (fuel wood, charcoal, agricultural residue) stoves is $\$ 1$ per $\mathrm{kW}$. However, it is assumed that $40 \%$ of fuel wood is used in "three-stone" fire, so that the weighted average cost is equivalent to $\$ 0.6$ per $\mathrm{kW}$.

\subsubsection{Definition of Scenarios}

As shown in Table 4, the following five scenarios are considered for the period 2020-2030:

(i) business as usual (BAU): continuing with the high use of fuel wood;

(ii) government intervention (GI): based on government's plans to introduce improved fuel wood and solar stoves;

(iii) further intervention (FI): assumes a much higher proportion of improved and solar stoves than planned by the government;

(iv) high economic growth 1 (HEG 1): assumes an increase in the use of kerosene and LPG for cooking; and

(v) high economic growth 2 (HEG 2): assumes an increased use of electrical stoves.

Each scenario assumes that the energy demand continues to grow by $5.3 \%$ annually, following the historical growth in the household energy demand in Nigeria [1,14] owing to the population growth. As can be seen in Table 4, this leads to almost 1000 PJ of useful energy consumption in 2030, a four-fold increase on the base year. This would require in total around 55 million of stoves in 2020 and 92.5 million in 2030, of which the majority would still be fuel wood stoves. 
Table 4. Contribution of different fuels and stove types in the household cooking sector for different scenarios.

\begin{tabular}{|c|c|c|c|c|c|c|c|c|c|c|c|}
\hline \multirow{2}{*}{$\begin{array}{c}\text { Useful Energy, Fuels } \\
\text { and Stoves }\end{array}$} & \multirow{2}{*}{$\begin{array}{l}\text { Base } \\
\text { Year } \\
2003\end{array}$} & \multicolumn{2}{|c|}{$\begin{array}{c}\text { Business as } \\
\text { Usual (BAU) }\end{array}$} & \multicolumn{2}{|c|}{$\begin{array}{c}\text { Government } \\
\text { Intervention (GI) }\end{array}$} & \multicolumn{2}{|c|}{$\begin{array}{c}\text { Further } \\
\text { Intervention (FI) }\end{array}$} & \multicolumn{2}{|c|}{$\begin{array}{c}\text { High Economic } \\
\text { Growth } 1 \text { (HEG 1) }\end{array}$} & \multicolumn{2}{|c|}{$\begin{array}{c}\text { High Economic } \\
\text { Growth } 2 \text { (HEG 2) }\end{array}$} \\
\hline & & 2020 & 2030 & 2020 & 2030 & 2020 & 2030 & 2020 & 2030 & 2020 & 2030 \\
\hline Total useful energy (PJ) & 247.9 & 596.3 & 999.4 & 596.3 & 999.4 & 596.3 & 999.4 & 596.3 & 999.4 & 596.3 & 999.4 \\
\hline \multicolumn{12}{|c|}{ Contribution to useful energy (\%) } \\
\hline Fuel wood & 85.2 & 85.2 & 85.2 & 84.2 & 84.0 & 61.4 & 42.6 & 62.9 & 54.2 & 63.9 & 46.9 \\
\hline Charcoal & 2.8 & 2.8 & 2.8 & 2.8 & 2.8 & 2.8 & 2.8 & 2.8 & 2.8 & 2.8 & 2.8 \\
\hline Agricultural residue & 1.1 & 1.1 & 1.1 & 1.1 & 1.1 & 1.1 & 1.1 & 1.1 & 1.1 & 1.1 & 1.1 \\
\hline Electricity & 0.1 & 0.1 & 0.1 & 0.1 & 0.1 & 0.1 & 0.1 & 0.1 & 0.1 & 12.9 & 25.7 \\
\hline Kerosene & 10.5 & 10.5 & 10.5 & 10.5 & 10.5 & 10.5 & 10.5 & 19.0 & 23.3 & 10.5 & 10.5 \\
\hline LPG & 0.2 & 0.2 & 0.2 & 0.2 & 0.2 & 0.2 & 0.2 & 13.0 & 17.3 & 0.2 & 0.2 \\
\hline Improved fuel wood & 0.0 & 0.0 & 0.0 & 0.9 & 1.1 & 21.3 & 38.4 & 0.9 & 1.1 & 8.5 & 12.8 \\
\hline Solar & 0.0 & 0.0 & 0.0 & 0.1 & 0.2 & 2.6 & 4.3 & 0.1 & 0.2 & 0.0 & 0.0 \\
\hline Total & 100 & 100 & 100 & 100 & 100 & 100 & 100 & 100 & 100 & 100 & 100 \\
\hline \multicolumn{12}{|c|}{ Number of stoves $(1000 \mathrm{~s})^{\mathrm{a}}$} \\
\hline Fuel wood & 19,565 & 47,041 & 78,842 & 46,489 & 77,916 & 33,901 & 39,421 & 34,729 & 50,155 & 35,281 & 43,400 \\
\hline Charcoal & 648 & 1546 & 2591 & 1546 & 2591 & 1546 & 2591 & 1546 & 2591 & 1546 & 2591 \\
\hline Agricultural residue & 250 & 607 & 1018 & 607 & 1018 & 607 & 1018 & 607 & 1018 & 607 & 1018 \\
\hline Electricity & 2407 & 55 & 93 & 55 & 93 & 55 & 93 & 55 & 93 & 7122 & 23,782 \\
\hline Kerosene & 56 & 5797 & 9716 & 5797 & 9716 & 5797 & 9716 & 10,490 & 21,561 & 5797 & 9716 \\
\hline LPG & 23 & 110 & 185 & 110 & 185 & 110 & 185 & 7178 & 16,009 & 110 & 185 \\
\hline Improved fuel wood & 0 & 0 & 0 & 4969 & 1018 & 11,760 & 35,534 & 4969 & 1018 & 4693 & 11,845 \\
\hline Solar & 0 & 0 & 0 & 55 & 185 & 1436 & 3979 & 55 & 185 & 0 & 0 \\
\hline Total & 22,949 & 55,156 & 92,445 & 59,628 & 92,722 & 55,212 & 92,537 & 59,629 & 92,630 & 55,156 & 92,537 \\
\hline
\end{tabular}

Note: a: Estimated using Equation (2). 
The scenarios consider the same types of stove as currently used but assume their differing penetration into the cooking energy mix. In addition, following the government policy [11], all scenarios but BAU assumes that a certain percentage of cooking energy will be provided by improved fuel wood stoves and solar stoves; the exception is HEG 2 which does not have the latter.

The improved fuel wood stoves are made of steel with a closed hearth [21] to increase energy efficiency, here assumed at 35\% [15] and a chimney to reduce indoor air pollution. These stoves can save $30 \%-38 \%$ of fuel wood, in addition to saving time [11]. They are assumed to last for 10 years [15], as opposed to the conventional stoves, which have a typical lifespan of five years (Table 1). For the solar stoves, box-type cookers are considered with a unit capacity of $0.34 \mathrm{~kW}$, an efficiency of $35 \%$ and a lifetime of 15 years [15].

The future costs of fuels and annual growth rates of costs (Table 5) have been determined using the EIA data [22]. The future capital costs of cooking stoves are assumed to be constant over the period (see Table 3). This is because the costs differ greatly by manufacturer, the country of origin, and region in Nigeria, so that projecting future costs is not feasible. The costs of improved fuel wood and solar stoves are assumed at $\$ 7$ and $\$ 35$ per $\mathrm{kW}$, respectively [16].

Table 5. Assumptions for future fuel costs (US\$2014).

\begin{tabular}{cccc}
\hline Fuels & Costs in 2020 (\$/t) & Costs in 2030 (\$/t) & Annual Growth Rate (\%) [22] \\
\hline Fuel wood & 30 & 30 & 0.1 \\
Agricultural residue & 5 & 5 & 0.1 \\
Charcoal & 50 & 51 & 0.1 \\
Kerosene (international) & 829 & 1061 & 2.5 \\
Kerosene (domestic) & 600 & 768 & 2.5 \\
LPG (domestic) & 1162 & 1458 & 2.3 \\
\hline
\end{tabular}

The following sections provide a description of each of the scenarios considered.

\section{(i) Business as Usual}

As the name suggests, this scenario assumes that the fuels and types of stove used today continue to be used in the future and no improved or solar stoves are introduced (Table 4). The majority (85\%) of stoves are still fuel wood-based, consuming 437 million tonnes of wood by 2030, four times higher than in the base year (Table 1).

\section{(ii) Government Intervention}

The government's plans to introduce improved fuel wood and solar stoves into the cooking mix [11] have been used to define this scenario. Based on these, 1 million of improved fuel wood and 185,000 of solar stoves will be used in the household cooking sector by 2030 (Table 4).

\section{(iii) Further Intervention}

This scenario assumes that government's targets for new cooking stoves may not be enough to reduce the environmental and health impacts and that a much higher proportion of improved fuel wool and solar stoves would be needed. Thus, it is assumed that the former replace around $40 \%$ and the later $4 \%$ of the conventional fuel wood stoves by 2030 , with a total of 35.5 and 1.4 million of each stove type integrated into the cooking energy mix (Table 4). 


\section{(iv) High Economic Growth 1}

With the average GDP growth of 5.4\% between 2010 and 2014 [23], it is expected that the economy will continue to grow in the short to medium term. In that case, it is likely that more people in the urban areas will move up the energy ladder by switching from fuel wood to LPG and kerosene stoves [24]. Moreover, with the estimated reserves of over 37 billion barrels of oil and 5 trillion $\mathrm{m}^{3}$ of natural gas [25], coupled with the on-going efforts to build more refineries and improve gas processing infrastructure in the country [26], it is assumed that the supply of fossil fuels in the country will increase in the future. Thus, this scenario is characterised by an increase in the use of kerosene and LPG for cooking. It is assumed that $23 \%$ of the energy demand will be met by 21.5 million kerosene stoves by 2030 , replacing the fuel wood cookers. Furthermore, 16 million of LPG stoves will provide 17\% of cooking energy in the same year, also replacing the fuel wood stoves. Improved wood and solar stoves are assumed to be introduced at the same rate as planned by the government in the GI scenario (Table 4).

\section{(v) High Economic Growth 2}

The electricity sector in Nigeria is set to grow over time [27]. There are also plans by the government to increase electricity access across the country from $40 \%$ in the early 2000 s to about $75 \%$ of the total population by 2025 [28]. Thus there is the possibility that, in the event of increased electricity availability in the future and increased income owing to a high economic growth, people in urban areas would switch to electricity for cooking to avoid the extra effort of buying and transporting kerosene, LPG and fuel wood. Therefore, it is assumed that $26 \%$ of the energy demand is met by almost 24 million of electric stoves by 2030 (Table 4). However, with the current high poverty levels of over $60 \%$ [2], it is expected that fuel wood will still dominate the sector in the short to medium term, especially in rural areas, with the conventional and improved stoves providing respectively $47 \%$ and $13 \%$ of the cooking energy by 2030 (Table 5).

\subsection{System Modelling}

\subsubsection{Life Cycle Assessment}

The environmental impacts from the household cooking sector have been evaluated using life cycle assessment (LCA), following the ISO 14040/44 guidelines [29,30]. As shown in Figure 2, the scope of the study is from "cradle to grave". The functional unit is defined as the 'annual useful heat consumption' for each time period considered, as follows (see Table 4):
○ $248 \mathrm{PJ}$ in the base year (2003);
○ 596 PJ in 2020; and
○ $999 \mathrm{PJ}$ in 2030.

The CML 2001 impacts assessment method [31] has been used to estimate the impacts, according to the following equations [32]:

$$
\begin{array}{cc}
B_{j}=\sum b_{j, i} x_{i} & (\text { t } \text { or MJ/year }) \\
E_{j}=\sum e_{k, j} B_{j} & \text { (t eq./year) }
\end{array}
$$

where $b_{j, I}$ is environmental burden $j$ from process or activity $i$, with burdens representing raw materials and energy used in the system and emissions to air, water and land; $x_{i}$ is mass or energy flow associated 
with process or activity $I$ and $e_{k, j}$ is relative contribution of burden $B_{j}$ to impact $E_{k}$ as defined by the CML 2001 method [31]. The following impacts are considered: global warming potential (GWP), abiotic depletion potential (ADP), acidification potential (AP), eutrophication potential (EP), human toxicity potential (HTP), ozone layer depletion potential (ODP) and photochemical oxidants creation potential (POCP). As indicated in Equation (4), the environmental impacts are expressed in tonne-equivalents of different substances; for example, the GWP is expressed in tonnes of $\mathrm{CO}_{2}$ eq., acidification in tonnes of $\mathrm{SO}_{2}$ eq., etc.

The biogenic carbon is excluded from the estimation of the GWP, as per standard LCA practice [33]. However, its influence on the results is explored later in the paper as part of a sensitivity analysis. Furthermore, $\mathrm{CO}_{2}$ emissions from flaring are also considered. Nigeria flares $70 \%-75 \%$ of the total associated gas produced during crude oil production [34,35]. Thus, in the base year a $70 \%$ gas flaring for the domestically-produced kerosene and LPG has been assumed. As the flaring is set to end in the future [35], the years 2020 and 2030 are modelled with zero gas flare for these fuels.

SimaPro 6 [36] has been used for the LCA modelling. The life cycle inventory data have been sourced from GEMIS 4.3 [15] and the databases available within SimaPro.

\subsubsection{Economic Costs}

The costs considered in this work comprise capital, fuel and total annual costs. The latter have been estimated as follows:

$$
T C=\sum A C c_{j}+\sum F C_{i} \quad(\$ / \text { year })
$$

where $T C$ is the total annual cost, $A C c_{j}$ annualised capital cost of stove type $j$ and $F C_{i}$ annual cost of fuel $i$. The annualised capital cost $A C C_{j}$ is calculated by multiplying the capital cost $C C_{j}$ of stove type $j$ by an annuity factor $f_{j}[15]$ :

$$
A C C_{j}=C C_{j} x f_{j} \quad(\$ / \text { year })
$$

with $f_{j}$ equal to:

$$
f_{j}=z(1+z)^{t} /\left[(1+z)^{t}-1\right]
$$

where $z$ is the discount rate (assumed at 13\% [37]) and $t$ the lifetime of technology (year). In addition, the unit cost of heat $U H C$ has been estimated for each period by dividing the total cost $T C$ by the total annual energy demand:

$$
U H C=T C / U E \quad(\$ / \mathrm{MJ})
$$

where $U E$ is the total annual useful energy estimated by Equation (1).

\section{Results and Discussion}

\subsection{Life Cycle Environmental Impacts}

As indicated Figure $3 \mathrm{a}-\mathrm{h}$ and Table $\mathrm{A} 1$ in the Appendix, all environmental impacts are expected to increase over the period across the scenarios owing to a growing heat demand, despite the assumed improvements in stove efficiency. As can also be inferred from the results, there is no overall "best" scenario with respect to the impacts, with each having advantages and disadvantages. For example, at 
the end of the period, HEG 2 is best for three impacts (EP, ODP and POCP) but also worst for the ADP. BAU is the best option for two impacts (ADP and HTP); however, it is the worst alternative for three (AP, EP and POCP). The lowest GWP (excluding biogenic $\mathrm{CO}_{2}$ ) is found for the FI scenario and the highest for HEG 1.

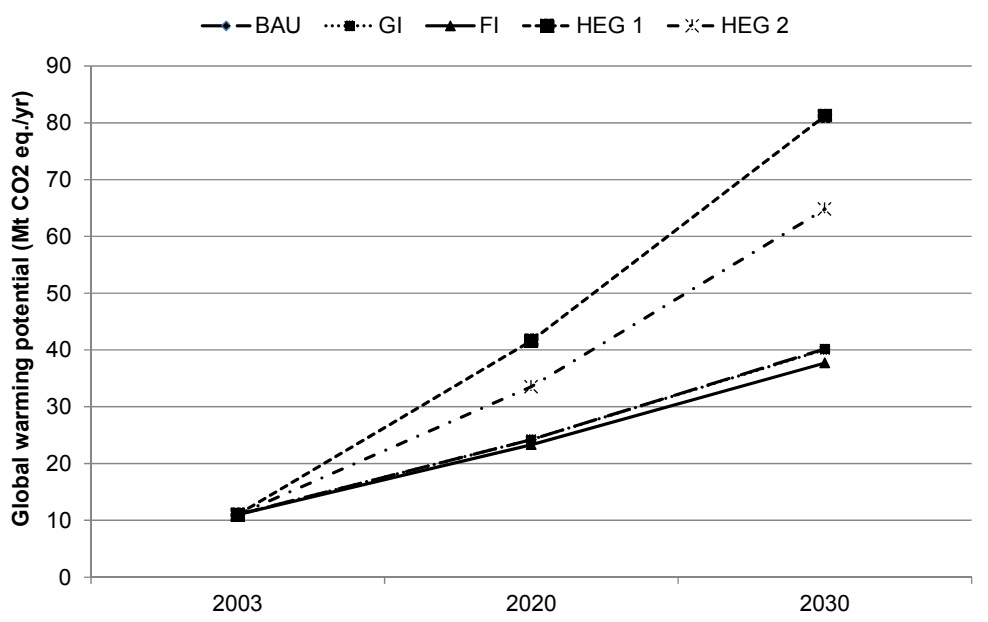

(a)

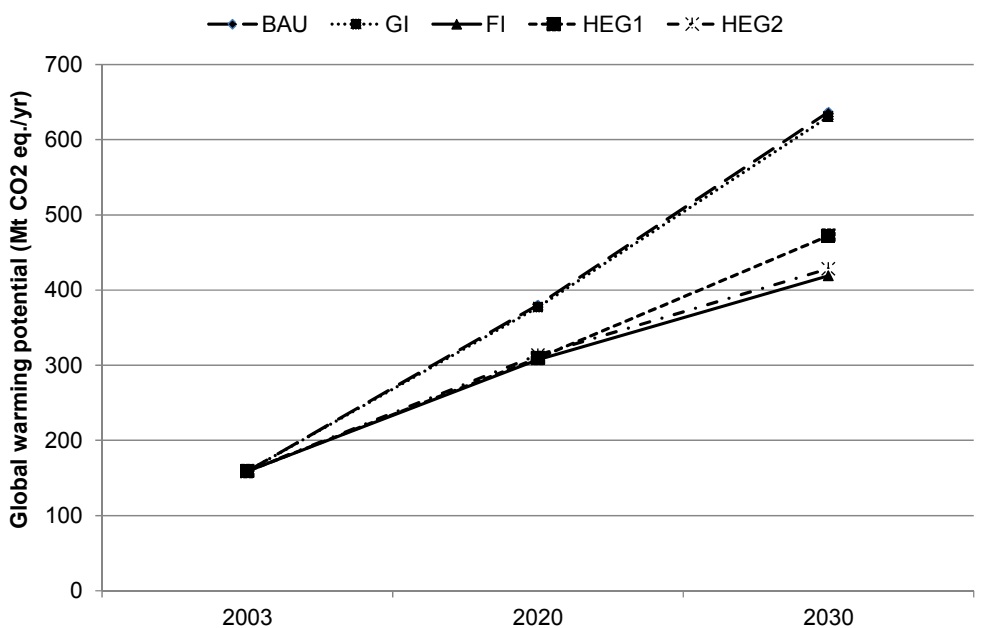

(b)

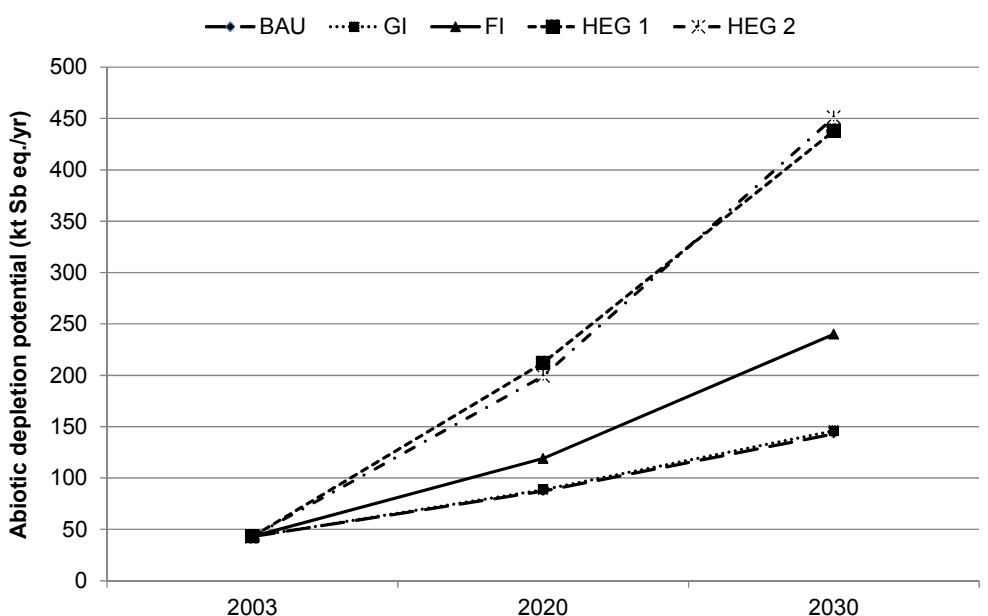

(c)

Figure 3. Cont. 


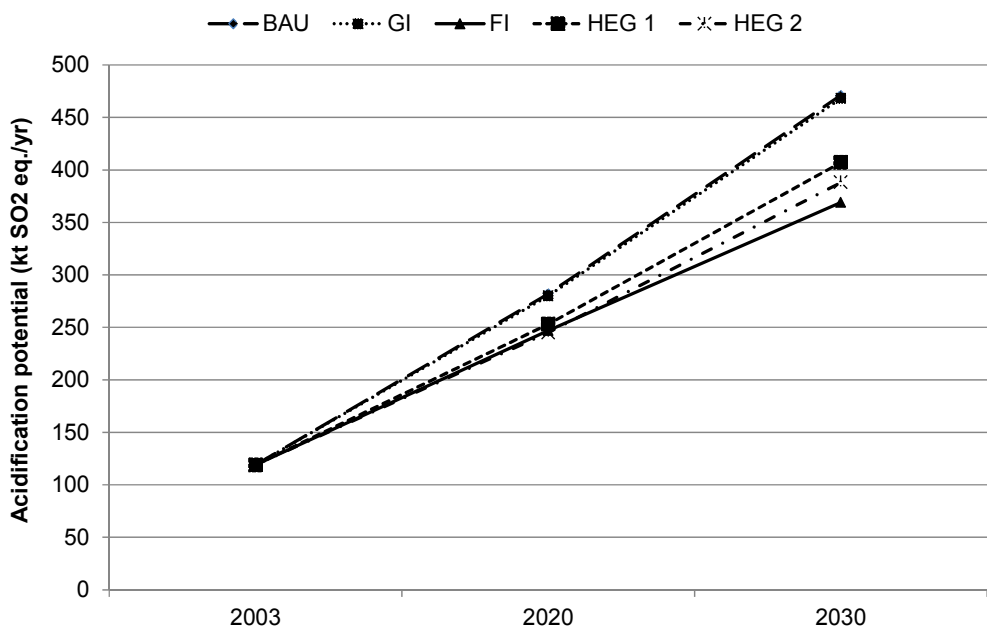

(d)

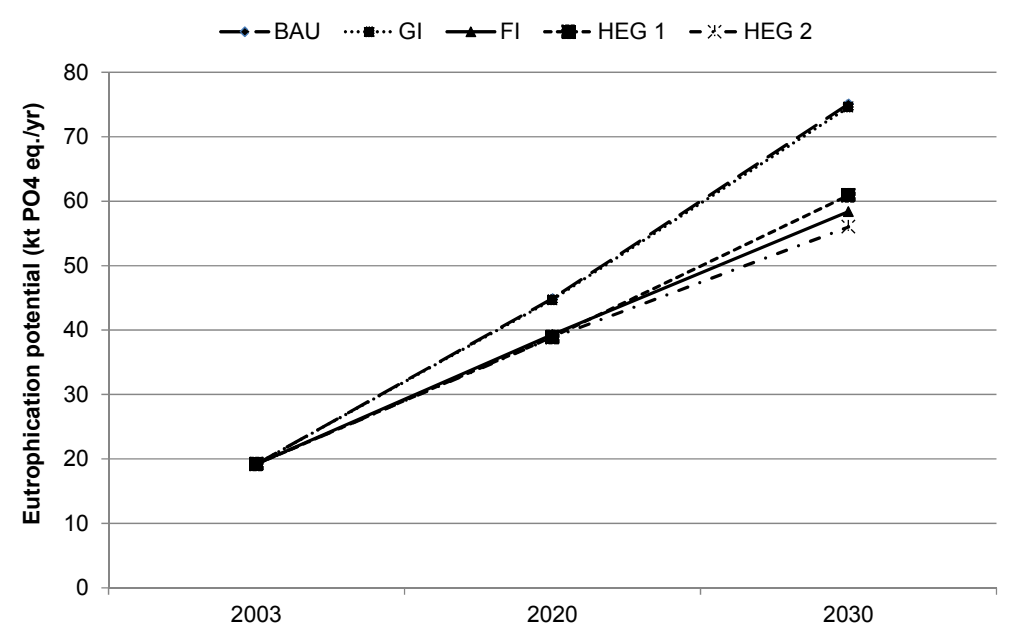

(e)

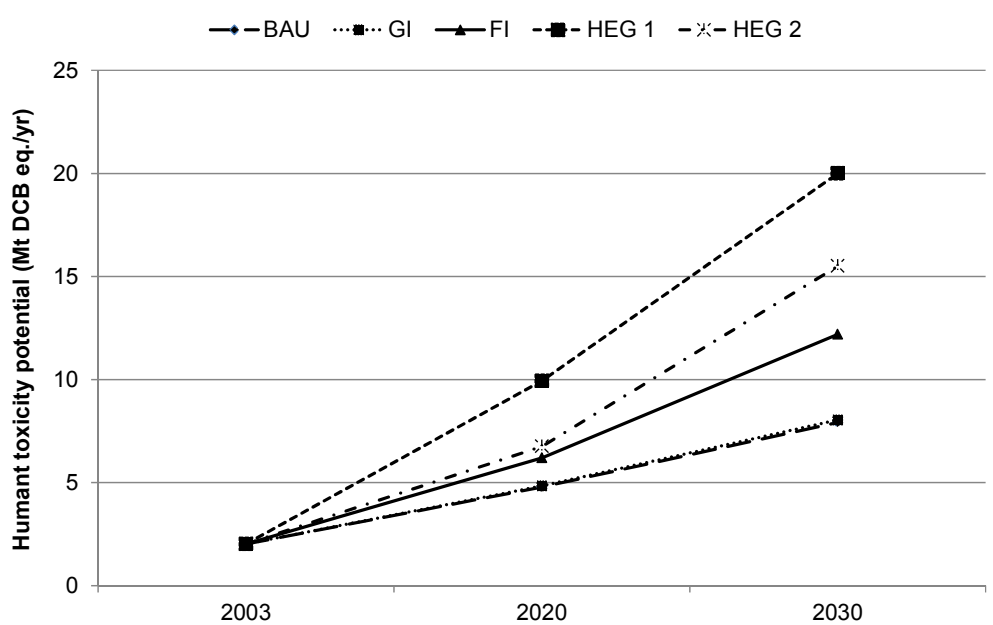

(f)

Figure 3. Cont. 


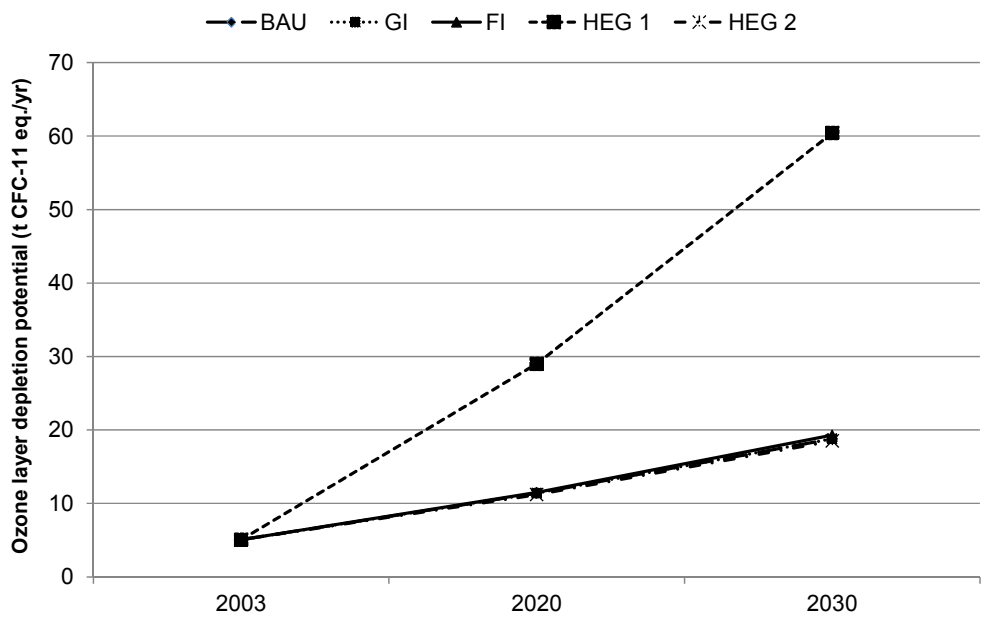

(g)

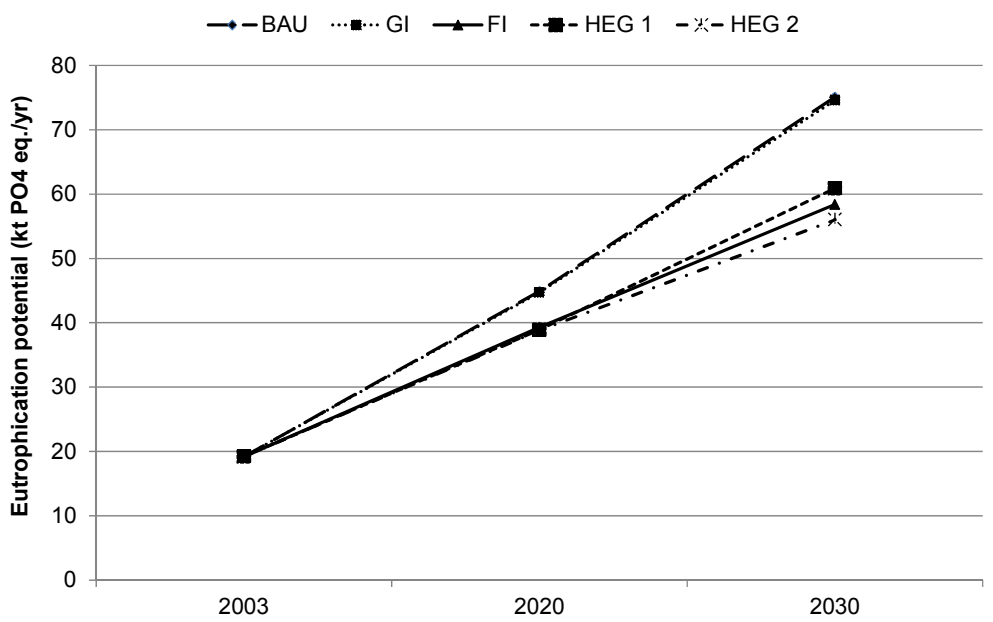

(h)

Figure 3. Estimated trends for the life cycle environmental impacts for different scenarios from 2003 to 2030. (a) Global warming potential (excluding biogenic $\mathrm{CO}_{2}$ ); (b) Global warming potential (including biogenic $\mathrm{CO}_{2}$ ); (c) Abiotic depletion potential; (d) Acidification potential; (e) Eutrophication potential; (f) Human toxicity potential; (g) Ozone layer depletion potential; (h) Photochemical oxidants creation potential.

To put these findings in context, the environmental impacts of different scenarios are compared in Table 6 to the current trends in the cooking sector, as exemplified by BAU. It is apparent that the government's plan to introduce the improved fuel wood and solar stoves considered in the GI scenario will make no difference to the impacts compared to the BAU trends, with most impacts remaining the same as in BAU. This is because the planned deployment of 1.2 million of new stoves by 2030 is far too low to have an effect. If, on the other hand, the number of stoves is increased significantly as in the FI scenario ( 40 million in 2030), significant reductions $(\sim 30 \%)$ in the AP, EP and POCP could be achieved. This is mainly due to the reduced consumption of fuel wood and the resulting lower emissions of $\mathrm{CO}, \mathrm{NOx}$ and SOx. The reduced fuel wood consumption also results in lower methane emissions and, thus, the GWP is reduced by 7\% (excluding biogenic $\mathrm{CO}_{2}$ ). However, in this scenario, the ADP increases by $40 \%$ and HTP by $35 \%$. This is because more materials and fuels are required to produce improved and solar stoves compared to the conventional fuel wood stoves. 
Table 6. Comparison of environmental impacts and costs with the BAU scenario.

\begin{tabular}{cccccccccc}
\hline \multirow{2}{*}{ Impacts and Costs } & \multicolumn{3}{c}{ Change Compared to BAU in 2020 (\%) } & \multicolumn{3}{c}{ Change Compared to BAU in 2030 (\%) } \\
\cline { 2 - 3 } & GI & FI & HEG 1 & HEG 2 & & GI & FI & HEG 1 & HEG 2 \\
\hline GWP (excl. biogenic $\mathrm{CO}_{2}$ ) & 0.0 & -3.9 & 41.8 & 27.8 & & -0.2 & -6.6 & 50.5 & 38.0 \\
GWP (incl. biogenic $\mathrm{CO}_{2}$ ) & -0.8 & -23.7 & -22.9 & -21.2 & & -1.0 & -52.0 & -34.8 & -48.7 \\
ADP & 1.6 & 26.7 & 58.9 & 56.2 & & 2.1 & 40.4 & 67.4 & 68.3 \\
AP & -0.7 & -14.2 & -11.5 & -15.1 & -0.6 & -27.6 & -15.7 & -21.4 \\
EP & -0.4 & -14.2 & -15.4 & -15.7 & -0.7 & -28.6 & -23.3 & -34.1 \\
HTP & 1.2 & 22.9 & 51.9 & 29.2 & & 1.5 & 35.1 & 60.4 & 48.9 \\
ODP & 0.0 & 0.9 & 60.7 & -1.8 & & 0.0 & 2.6 & 68.9 & -1.6 \\
POCP & -0.5 & -13.7 & -20.2 & -18.6 & -0.7 & -27.0 & -30.6 & -41.0 \\
Capital costs & 4.8 & 55.2 & 89.3 & 89.4 & & 6.9 & 69.8 & 91.8 & 94.3 \\
Total and unit heat costs & -0.5 & -16.2 & 24.9 & 3.7 & -0.7 & -32.1 & 37.4 & 2.7 \\
\hline
\end{tabular}

The HEG 1 scenario, which is characterised by an increase in kerosene and LPG consumption, shows improvements in three impact categories - AP, EP, and POCP — which are lower respectively by $16 \%$, $23 \%$ and $31 \%$ in 2030 compared to the BAU scenario. The reason is the same as that for the FI scenario, i.e., the reduced use of fuel wood. However, the GWP (excluding biogenic $\mathrm{CO}_{2}$ ), ADP, HTP, and ODP are higher by two to three times. This is mainly due to the increased production and consumption of fossil fuels in this scenario. The HEG 2 scenario, with a high number of electric and improved fuel wood stoves, shows a similar trend as HEG 1. However, the increase in the impacts for this scenario is due to the use of natural gas and coal for electricity generation (for the impacts associated with the electricity mix, see Gujba et al. [27]). These results are discussed in the following sections in more detail for each environmental impact.

\subsubsection{Global Warming Potential}

Compared to the base year, the total GWP in the BAU scenario increases by almost four times over the period, from 11 to 40 million $\mathrm{C} \mathrm{CO}_{2}$ eq. (Figure $3 \mathrm{a}$ ). Carbon dioxide emissions account for about $50 \%$ of this impact, $85 \%$ of which is due to the use of kerosene stoves. Methane contributes around $30 \%$ to the total GWP, $90 \%$ of which is related to fuel wood consumption.

Even for the best scenario, FI, the GWP is still 3.4 times higher than in the base year; in the worst case (HEG 1), it goes up by 7.4 times, to 81 million $\mathrm{t} \mathrm{CO}_{2}$ eq. in 2030.

However, biogenic $\mathrm{CO}_{2}$ is not considered in the above results. As mentioned before, this is a standard LCA practice since $\mathrm{CO}_{2}$ emitted during biomass combustion is assumed to be sequestered from the atmosphere by biomass during its growth. Nevertheless, a sensitivity analysis has been carried out to examine the effect of including biogenic $\mathrm{CO}_{2}$ in the estimation of the GWP. As indicated in Figure $3 b$, the GWP would be higher by an order of magnitude compared to the GWP without biogenic $\mathrm{CO}_{2}$. For example, in 2030, the impact for the BAU and GI scenarios is 16 times higher with than without the biogenic $\mathrm{CO}_{2}$; for FI, it is 11 times greater and for the HEG scenarios six to seven times bigger. These findings are particularly important because the used biomass in Nigeria is not replaced sustainably, so that the potential for sequestering biogenic $\mathrm{CO}_{2}$ is diminishing. Even if half of the cleared forests were 
regenerated, the GWP in 2030 would still be three to eight times higher with than without the biogenic $\mathrm{CO}_{2}$ across all the scenarios.

The inclusion of biogenic $\mathrm{CO} 2$ also changes the ranking of the scenarios with BAU and GI being the worst options (Table 6). FI and HEG 2 are now comparable, with the GWP in 2030 half that of the BAU, followed by HEG 1 with 35\% lower GWP than BAU. This is largely because the BAU and GI scenarios are dominated by biomass so their GWP is much higher when the biogenic $\mathrm{CO} 2$ is considered than for the other three scenarios. Therefore, these results show clearly the crucial importance of sustainable forest management in Nigeria to avoid a significant increase of GHG emissions from biomass use.

\subsubsection{Abiotic Depletion Potential}

The total ADP in the base year is estimated at 43,000 $\mathrm{t} \mathrm{Sb}$ eq. In the best (BAU) scenario, it increases to 143,000 tonnes by 2030 , or over three times (Figure $3 \mathrm{c}$ ). This impact is mainly due to the use of oil, accounting for about $70 \%$ of the total in the base year and $80 \%$ in BAU in 2030 . The lower contribution of this fuel in the base year is due to the increased contribution from petroleum gas and associated gas flaring, which accounts for $20 \%$ of the resource depletion. Its contribution reduces to $5 \%$ in the subsequent periods because of the assumed zero gas flare in the future.

The highest depletion of resources is found for HEG 2, totalling 451,000 t Sb eq. in 2030-this represents a ten-fold increase on the base year. HEG 1 follows closely with 438,000 tonnes. For the former, this is mainly because of the higher use of electricity and for the latter the greater consumption of kerosene for cooking.

\subsubsection{Acidification and Eutrophication Potentials}

Both the AP and EP are expected to be three to four times higher by 2030 than in the base year. For example, in BAU, the AP increases from 120,000 to 470,000 $\mathrm{t} \mathrm{SO}_{2}$ eq. (Figure 3d) and the EP from 19,200 to 75,000 t $\mathrm{PO}_{4}$ eq. (Figure 3e). For the best scenario, FI, these two impacts are still three times higher than in the base year. NOx and SOx emissions from the burning of fuel wood are the major contributors to the AP and NOx to the EP across the scenarios.

\subsubsection{Human Toxicity Potential}

In the base year, the HTP is estimated at $2 \mathrm{Mt} 1,4$ dichlorobenzene (DCB) eq. (Figure $3 \mathrm{f}$ ) and by 2030, it is expected to increase by between four times (BAU and IF) and 10 times (HEG 1). Upstream activities in the life cycle of fuels and materials are mainly responsible for this impact. For the example of BAU, crude oil production accounts for $55 \%$ of the HTP, mostly because of water emissions of barite and polyaromatic hydrocarbons. The latter, emitted to air from the production of aluminium, contribute a further $14 \%$. Combustion of fuel wood is responsible for around $10 \%$ of this impact, owing to the NOx emissions. 


\subsubsection{Ozone Layer Depletion Potential}

In all the scenarios, ozone layer depletion would increase by four times on the base year by 2030, from 5 to $20 \mathrm{t} \mathrm{CFC-11} \mathrm{eq.} \mathrm{(Figure} \mathrm{3g).} \mathrm{The} \mathrm{exception} \mathrm{to} \mathrm{this} \mathrm{is} \mathrm{HEG} \mathrm{1,} \mathrm{for} \mathrm{which} \mathrm{the} \mathrm{ODP} \mathrm{would} \mathrm{be}$ 12 times higher, owing to the higher use of kerosene and LPG. Emissions of bromotrifluoromethane, associated with the production of crude oil, are the main cause of this impact.

\subsubsection{Photochemical Oxidation Potential}

For the POCP, the future trends are similar to those for the AP and EP: it increases from $35,000 \mathrm{t} \mathrm{C}_{2} \mathrm{H}_{4}$ eq. in the base year by three times for BAU and FI and four times for the other three scenarios by 2030 (Figure 3h). Most of this impact is due to carbon monoxide emitted during the combustion of biomass.

\subsection{Economic Costs}

Like the environmental impacts, the costs also increase in the future in all the scenarios (Figure 4a,b and Table A1). For the capital costs, the best option would be BAU followed by GI and the worst HEG 2. However, for the total and unit heat costs, FI emerges at the best alternative and HEG 1 as the worst. These findings are discussed in more detail below.

\subsubsection{Capital Costs}

As can be seen in Figure 4a and Table A1, the total capital costs go up significantly by the end of the period, increasing by between four to 70 times on the base year, depending on the scenario. As mentioned earlier, BAU has the lowest costs, estimated at $\$ 280$ million/year in 2030, up from $\$ 69$ million/year in the base year. Kerosene stoves contribute most to the capital costs (43\%), although their contribution to the useful heat output is only $10 \%$. On the other hand, the contribution to the costs from fuel wood stoves is $35 \%$, while they provide $85 \%$ of the heat energy output. This is because kerosene stoves are 10 times more expensive than the fuel wood cookers (see Table 3). The cost of LPG stoves is more than a 100fold higher than that of the fuel wood stoves, so that they contribute $15 \%$ of the total capital costs despite providing only $0.2 \%$ of the useful heat demand.

As indicated in Table 6, the capital costs for the GI scenario are close to those of the BAU, being 7\% higher in 2030. This increase is due to the higher capital costs of the improved fuel wood and solar stoves compared to the conventional stoves. For the same reason, the capital costs in the FI scenario increase more significantly (70\% in 2030) as the number of these stoves is much higher than in BAU. Similarly, as the number of kerosene, LPG and electric stoves increases in the HEG 1 and HEG 2 scenarios, the capital costs increase even further compared to BAU $(>90 \%)$.

\subsubsection{Total and Unit Heat Costs}

The total cost in the base year is estimated at $\$ 3.8$ billion/year, increasing to around $\$ 17.4$ billion/year in 2030 for the BAU scenario (Figure 4b). The vast majority of this is due to the costs of fuels (98\%), with fuel wood contributing $78 \%$ and kerosene $20 \%$. The total costs for GI are similar, estimated at $\$ 17.3$ 
billion. The FI scenario shows the most significant decrease in the total costs (32\%) compared to BAU (Table 6). This is attributed to the increased number of improved fuel wood and solar stoves replacing the conventional stoves, which leads to the lower fuel costs, and despite the increased capital costs, to an overall decrease in the total costs. On the other hand, the total cost for the HEG 1 scenario is significantly higher (37\%) than that in the BAU scenario. This is mainly due to the use of LPG and kerosene stoves, which are characterised by high fuel and capital costs. The total costs of HEG 2 show only a modest increase relative to BAU (3\%). The main reasons for this are much higher energy efficiencies of electric and improved fuel wood stoves which reduces fuel consumption.

The same trends apply to the unit heat costs, which would increase from $1.52 \$$ cents/MJ in the base year to 1.74 \$cents/MJ in 2030 for BAU and 2.78 \$cents/MJ for HEG 1. In the best case (FI), the cost is around 30\% lower than in the base year, estimated at 1.32 \$cents/MJ.

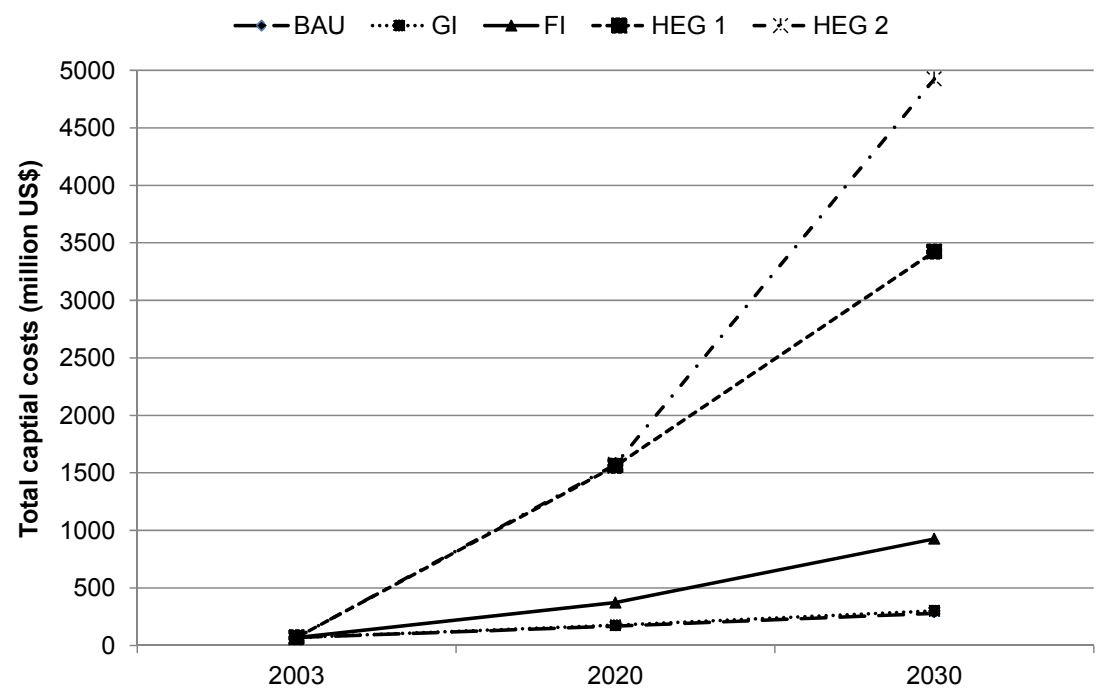

(a)

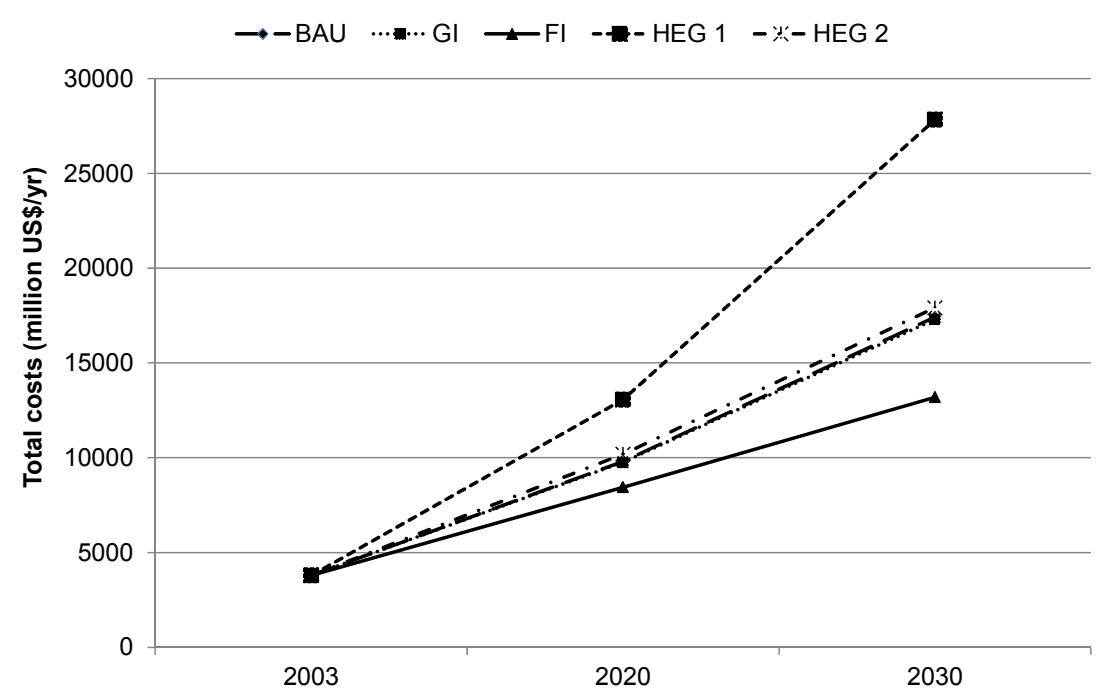

(b)

Figure 4. Capital and total annual costs for different scenarios from 2003 to 2030. (a) Capital costs; (b) Total annual costs. 


\section{Conclusions and Policy Recommendations}

This paper has considered the potential environmental impacts and costs in the household cooking sector in Nigeria up to the year 2030. The results suggest that both the impacts and costs would increase significantly if the heat demand continued to grow at the current rates. In particular, if business as usual continues, the life cycle environmental impacts will increase by three to four times, and the costs will be higher by four to five times by 2030. This is mainly due to the consumption of fuel wood rising by four times. This will also exacerbate the already high impacts on human health from indoor air pollution, which could increase the death toll by four-fold, from 79,000 in the base year to 316,000 in 2030.

Thus there is a clear need to chart a new course for the future household cooking sector in Nigeria. This includes improving the efficiency of the biomass economy and promoting other cooking technologies. This would also help to reduce the huge pressure on biomass reserves, the consumption of which is expected to reach 437 million tonnes by 2030 at the current consumption trends. The government has already drawn up plans to introduce improved fuel wood and solar stoves in Nigeria, which has been considered in this research, in addition to the BAU trends. It is also possible that other factors, such as high economic growth, greater availability and affordability of other fuels, could result in a shift towards a more fossil fuel-based trajectory where consumers move up the energy ladder. These possible trends have also been analysed in this study.

The results from these different pathways show mixed results. The analysis of the government's plans to introduce improved fuel wood and solar stoves (GI scenario) shows that there would be no environmental advantages over the current system. This is because the number of stoves proposed by the government is far too low ( $\sim 1.2$ million by 2030) to bring about the significant reduction in the environmental impacts needed for this sector. As shown in the FI scenario, the number of the advanced stoves would have to be at least 30 times higher than planned to have a noticeable effect; however, while some impacts would be reduced relative to BAU, including the global warming potential (7\%), acidification and eutrophication ( $30 \%)$, some other impacts would go up significantly, notably human toxicity along the supply chain $(35 \%)$. At the same time, the number of deaths from indoor air pollution would be two times lower than in BAU.

If, on the other hand, fossil fuel stoves (LPG and kerosene) are favoured, as defined in HEG 1, some environmental impacts would decrease relative to BAU (acidification and eutrophication) but the global warming potential, resource depletion, human toxicity and ozone layer depletion would increase significantly (50\%-70\%). The increased use of electrical and improved fuel wood stoves, as considered in HEG 2, would yield similar results as the fossil fuel based scenario but with a somewhat lower increase in the global warming potential $(\sim 40 \%)$ and a lower ozone layer depletion than in BAU $(2 \%)$.

Furthermore, it is important to emphasise that, in addition to reducing the environmental impacts, the pressure on biomass and indoor pollution are reduced in all the scenarios except in BAU. This is critical in view of the fact that deforestation, soil depletion and indoor air pollution have an immediate impact on the wellbeing of rural communities in Nigeria. Furthermore, as shown in this work, unsustainable use of biomass could increase the global warming potential from the cooking sector by a factor of 10 . Hence, sustainable development to reduce the rate of biomass consumption and increase reforestation in the medium- to long-term future is essential, requiring a concerted action of a range of institutions in Nigeria, including those in the energy, forestry, agriculture and health sectors. In the end, the effectiveness of the 
Nigerian biomass programme will be measured against the twin objectives of how well it has led to improvements in access to clean and reliable cooking fuels and how it has contributed to the enhancement of the biomass stock in the country.

On the question of costs, the FI scenario appears to be the least costly pathway to pursue with a unit heat cost of 1.32 \$cents/MJ in 2030, compared to 1.74 \$cents/MJ for BAU. However, its capital costs are around three times higher than for BAU. Nevertheless, there is the added dimension of creating more employment if the FI path is followed, given the labour intensive nature of the activities where much of the value added balance remains at the local level. However, this pathway may require high levels of organisation and institutional coordination to establish the advanced stoves market and ensure the necessary quality controls are in place. The HEG 1 and HEG 2 scenarios are more costly (2.78 and 1.79 \$cents/MJ, respectively), mainly because of the high costs of the appliances and fuels. The GI scenario is comparable to BAU but, as discussed above, it does not offer any environmental advantages over the BAU.

In conclusion, the following policy recommendations are made based on the findings of this research:

- It is evident that biomass will still be a dominant fuel in the household cooking sector in the long run. Thus, developing a sustainable development plan to protect forests and replenish biomass resources should be a priority for the Nigerian government; this would also help to reduce GHG emissions from the sector.

- Advanced cooking technologies, such as improved fuel wood and solar stoves, would help towards addressing this issue and should be introduced by the government as soon as possible. However, the number of stoves needs to be increased significantly from that currently planned if some of the key environmental and health impacts from air pollution are to be reduced. Care should be taken to consider carefully the environmental impacts that would increase through such an intervention, particularly human toxicity along the supply chain, so that direct human health impacts from indoor air pollution are not reduced at the expense of health impacts elsewhere in the supply chain.

- Introducing the advanced stoves will require government subsidies as most people will not be able to afford them. These should be aimed at helping those below the poverty line, particularly in rural communities. Robust mechanisms should be put in place to minimise the potential for corruption.

- Introducing LPG and electricity stoves could help to reduce the pressure on biomass as well as health impacts from indoor pollution but would lead to an increase in climate change impacts and abiotic resource depletion. Therefore, this option should be considered carefully, as there are significant environmental as well as economic trade-offs.

Ultimately, the main goal for the government should be alleviation of poverty, as this would increase energy affordability, enabling people to move up the energy ladder and use more efficient appliances. This would in turn help to reduce the environmental and health impacts in this sector while at the same time improving access to clean cooking fuels and reducing pressures on national biomass reserves.

\section{Conflicts of Interest}

The authors declare no conflict of interest. 


\section{Appendix}

Table A1. Life cycle environmental impacts and costs for different scenarios.

\begin{tabular}{|c|c|c|c|c|c|c|c|c|c|c|c|}
\hline Impacts/Costs & $\begin{array}{c}\text { Base Year } \\
\text { (2003) }\end{array}$ & $\begin{array}{l}\text { BAU } \\
(2020)\end{array}$ & $\begin{array}{c}\text { GI } \\
(2020)\end{array}$ & $\begin{array}{c}\text { FI } \\
(2020)\end{array}$ & $\begin{array}{l}\text { HEG } 1 \\
(2020)\end{array}$ & $\begin{array}{l}\text { HEG } 2 \\
(2020)\end{array}$ & $\begin{array}{l}\text { BAU } \\
(2030)\end{array}$ & $\begin{array}{c}\text { GI } \\
(2030)\end{array}$ & $\begin{array}{c}\text { FI } \\
(2030)\end{array}$ & $\begin{array}{l}\text { HEG } 1 \\
(2030)\end{array}$ & $\begin{array}{l}\text { HEG } 2 \\
(2030) \\
\end{array}$ \\
\hline $\begin{array}{c}\text { GWP excluding } \\
\text { biogenic } \mathrm{CO}_{2} \\
\left(\mathrm{Mt} \mathrm{CO}_{2} \text { eq./year) }\right.\end{array}$ & 11.0 & 24.2 & 24.2 & 23.3 & 41.6 & 33.5 & 40.2 & 40.1 & 37.7 & 81.2 & 64.8 \\
\hline $\begin{array}{c}\text { GWP including } \\
\text { biogenic } \mathrm{CO}_{2} \\
\left(\mathrm{Mt} \mathrm{CO}_{2} \text { eq./year) }\right.\end{array}$ & 159 & 380 & 377 & 307 & 309 & 314 & 637 & 631 & 419 & 472 & 428 \\
\hline $\begin{array}{c}\text { ADP } \\
\text { (kt Sb eq./year) }\end{array}$ & 43.1 & 87.2 & 88.6 & 119.0 & 212.0 & 199.0 & 143.0 & 146.0 & 240.0 & 438.0 & 451.0 \\
\hline $\begin{array}{c}\mathrm{AP} \\
\left(\mathrm{kt} \mathrm{SO}_{2} \text { eq./year) }\right.\end{array}$ & 119.0 & 282.0 & 280.0 & 247.0 & 253.0 & 245.0 & 471.0 & 468.0 & 369.0 & 407.0 & 388.0 \\
\hline $\begin{array}{c}\text { EP } \\
\left(\mathrm{kt} \mathrm{PO}_{4} \text { eq./year) }\right. \\
\end{array}$ & 19.2 & 44.9 & 44.7 & 39.3 & 38.9 & 38.8 & 75.1 & 74.6 & 58.4 & 60.9 & 56.0 \\
\hline $\begin{array}{c}\text { HTP } \\
\text { (Mt 1,4-DCB eq./year) } \\
\end{array}$ & 2.0 & 4.8 & 4.8 & 6.2 & 9.9 & 6.8 & 7.9 & 8.0 & 12.2 & 20.0 & 15.5 \\
\hline $\begin{array}{c}\text { ODP } \\
\text { (t CFC-11 eq./year) }\end{array}$ & 5.1 & 11.4 & 11.4 & 11.5 & 29.0 & 11.2 & 18.8 & 18.8 & 19.3 & 60.4 & 18.5 \\
\hline $\begin{array}{c}\text { POCP } \\
\text { (kt } \mathrm{C}_{2} \mathrm{H}_{4} \text { eq./year) }\end{array}$ & 34.9 & 84.0 & 83.6 & 73.9 & 69.9 & 70.8 & 141.0 & 140.0 & 111.0 & 108.0 & 100.0 \\
\hline $\begin{array}{l}\text { Capital costs } \\
\text { (\$ million) }\end{array}$ & 69 & 167 & 175 & 373 & 1561 & 1573 & 280 & 300 & 927 & 3424 & 4925 \\
\hline $\begin{array}{c}\text { Total costs } \\
\text { (\$ million/year) }\end{array}$ & 3787 & 9813 & 9765 & 8446 & 13,068 & 10,188 & 17,424 & 17,303 & 13,189 & 27,830 & 17,908 \\
\hline $\begin{array}{l}\text { Unit heat costs } \\
\text { (\$cents/MJ) }\end{array}$ & 1.52 & 1.65 & 1.63 & 1.42 & 2.19 & 1.71 & 1.74 & 1.73 & 1.33 & 2.78 & 1.79 \\
\hline
\end{tabular}

\section{References}

1. International Energy Agency. Energy Balances for Nigeria. Available online: http://www.iea.org/ Textbase/stats/index.asp (accessed on 16 March 2015).

2. Bello, M.A.; Roslan, A.H. Has Poverty Reduced in Nigeria 20 Years After? Eur. J. Soc. Sci. 2010, $15,7-17$.

3. Babatunde, M.A.; Shuaibu, M.I. The Demand for Residential Electricity in Nigeria: A Bound Testing Approach. In proceedings of Second International Workshop on Empirical Methods in Energy Economics, University of Alberta, Edmonton, AB, Canada, 28-29 August 2009.

4. Sambo, A.S. Strategic Developments in Renewable Energy in Nigeria. International Association of Energy Economics. Third Quarter 2009, pp. 15-19. Available online: http://www.iaee.org/en/ publications/newsletterdl.aspx?id=75 (accessed on 16 March 2015).

5. Obadote, D.J. Energy Crisis in Nigeria: Technical Issues and Solutions. In Proceedings of the Power Sector Prayer Conference, Abuja, Nigeria, 25-27 June 2009. 
6. The World Bank Group (WBG). Nigeria Data Profile. Available online: http://data.worldbank.org/ country/nigeria (accessed on 16 March 2015).

7. Nasiru, I.M. Desertification in the Dry Lands of Nigeria and its Consequences. Available online: http://fab.utm.my/wp-content/uploads/2011/10/cStudents_student3Seminar200708.pdf (accessed on 16 March 2015).

8. Food and Agriculture Organisation of the United Nations. Global Forest Resources Assessment 2005; FAO Forestry Paper 147; 2006. Available online: http://ftp://ftp.fao.org/docrep/fao/ 008/A0400E/A0400E00.pdf (accessed on 16 March 2015).

9. Smith, K.R.; Mehta, S. The Burden of Disease from Indoor Air Pollution in Developing Countries: Comparison of Estimates. Int. J. Hyg. Environ. Health 2003, 206, 279-289.

10. World Health Organisation. Indoor Air Pollution: National Burden of Disease Estimates 2007. Available online: http://www.who.int/indoorair/publications/indoor_air_national_burden_ estimate_revised.pdf (accessed on 16 March 2015).

11. Energy Commission of Nigeria; United Nations Development Programme. Renewable Energy Master Plan. Final Report, November 2005. Available online: http:/www.iceednigeria.org/ workspace/uploads/nov.-2005.pdf (accessed on 16 March 2015).

12. Global Alliance for Clean Cookstoves. Clean Cookstoves and Fuels Carbon Project: A Catalogue of Carbon Offsets for Sale. Available online: http://cleancookstoves.org/resources_files/ carbon-credit-offsets-catalog.pdf (accessed on 28 May 2015).

13. United Nations Statistics Division. Energy Statistics: Nigeria. Available online: http://data.un.org/ Search.aspx?q=Nigeria (accessed on 16 March 2015).

14. Dayo, F.B.; Adegbulugbe, A.O.; Ibitoye, F.; Adenikinju, A. Estimating the Economic Benefits of Kyoto Protocol for the Nigerian Economy; Report for UNIDO; 2004. Available online: https://www.unido.org/fileadmin/import/29638_Nigeria_Study_CR3.pdf (accessed on 16 March 2015).

15. International Institute for Sustainability Analysis and Strategy (IINAS). Global Emission Model for Integrated Systems (GEMIS); Version 4.3; IINAS: Darmstadt, Germany, 2006.

16. Energy Commission of Nigeria (ECN); The International Atomic Energy Agency. Energy Master Plan Study for Nigeria; ECN: Abuja, Nigeria, 2004.

17. Organisation of Petroleum Exporting Countries (OPEC). Monthly Oil Market Report. December 2003. Available online: http://www.opec.org/opec_web/static_files_project/media/downloads/ publications/MOMR_122003.pdf (accessed on 16 March 2015).

18. Nigerian National Petroleum Corporation. Annual Statistical Bulletin 2003. Available online: www.nnpcgroup.com/Portals/0/Monthly\%20Performance/2003\%20Annual\%20Statistical\%20Bul letin\%20ASB\%20Old\%20Version.pdf (accessed on 16 March 2015).

19. Energy Sector Management Assistance Program. Nigerian LP Gas Sector Improvement Study; Technical Paper 056; 2004. Available online: https://openknowledge.worldbank.org/handle/ 10986/18859 (accessed on 16 March 2015).

20. U.S. Department of Labor Bureau of Labor Statistic. US Inflation Calculator. Consumer Price Index Data from 1913 to 2015. Available online: www.usinflationcalculator.com/inflation/consumerprice-index-and-annual-percent-changes-from-1913-to-2008 (accessed on 16 March 2015). 
21. Ayo, S.A. Design, Construction and Testing of an Improved Wood Stove. AU J. Technol. 2009, 13, $12-18$.

22. Energy Information Administration. Energy Forecasts and Analysis. Available online: http://www.eia.doe.gov/oiaf/forecasting.html (accessed on 16 March 2015).

23. The World Bank. GDP Growth (Annual \%) - Nigeria. Available online: http://data.worldbank.org/ indicator/NY.GDP.MKTP.KD.ZG/countries/NG?display=default (accessed on 16 March 2015).

24. Burning Issues. The Energy Ladder: A Concept in Fuel Cleanliness. November 2002. Available online: http://www.burningissues.org/energy-ladder.htm (accessed on 16 March 2015).

25. Organisation of Petroleum Exporting Countries. Annual Statistical Bulletin 2012. Available online: http://www.opec.org/opec_web/static_files_project/media/downloads/publications/ASB2013.pdf (accessed on 16 March 2015).

26. US Energy Information Administration. Nigeria. Available online: http://www.eia.gov/countries/ cab.cfm?fips=ni (accessed on 16 March 2015).

27. Gujba, H.; Mulugetta, Y.; Azapagic, A. Environmental and Economic Appraisal of Power Generation Capacity Expansion Plan in Nigeria. Energy Policy 2010, 38, 5636-5652.

28. Energy Commission of Nigeria. National Energy Policy. Document Presented to the Presidency, 2003. Available online: http://www.energy.gov.ng/index.php?option=com_docman\&task=cat view\&Itemid=\&gid=19\&orderby=dmdate published\&ascdesc=DESC (accessed on 16 March 2015).

29. International Organization for Standardization (ISO). ISO 14040_Environmental Management_Life Cycle Assessment-Principles and Framework; ISO: Geneva, Switzerland, 2006.

30. International Organization for Standardization (ISO). ISO 14044-Environmental Management-Life Cycle Assessment-Requirements and Guidelines; ISO: Geneva, Switzerland, 2006.

31. Guinée, J.B.; Gorrée, M.; Heijungs, R.; Huppes, G.; Kleijn, R.; van Oers, L.; Wegener Sleeswijk, A.; Suh, S.; udo de Haes, H.A.; de Bruijn, H.; et al. Life Cycle Assessment: An Operational Guide to the ISO Standards; Kluwer Academic Publishers: Dordrecht, The Netherlands, 2001; Parts 1, 2a \& 2b.

32. Azapagic, A.; Pettit, C.; Sinclair, P. A Life Cycle Approach to Mapping the Flows of Pollutants in the Urban Environment. Clean Technol. Environ. Policy 2007, 9, 199-214.

33. International Organization for Standardization (ISO). ISO 14067:2013 Greenhouse Gases-Carbon Footprint of Products-Requirements and Guidelines for Quantification and Communication; International Organisation for Standardisation: Geneva, Switzerland, 2013.

34. Nigerian National Petroleum Corporation. Gas Production. Available online: http://www.nnpcgroup.com/NNPCBusiness/UpstreamVentures/GasProduction.aspx (accessed on 16 March 2015).

35. Sonibare, J.A.; Akeredolu, F.A. Natural Gas Domestic Market Development for Total Elimination of Routine Flares in Nigeria's Upstream Petroleum Operations. Energy Policy 2006, 34, 743-753.

36. Pré Consultants. SimaPro 6; Pré Consultants: Amersfoort, The Netherlands, 2010.

37. Central Bank of Nigeria. Economic Report 2006. Available online: http://www.cenbank.org (accessed on 16 March 2015).

(C) 2015 by the authors; licensee MDPI, Basel, Switzerland. This article is an open access article distributed under the terms and conditions of the Creative Commons Attribution license (http://creativecommons.org/licenses/by/4.0/). 